\title{
Diagênese dos arenitos da Tectonossequência Rifte na Bacia do Araripe, NE do Brasil
}

\author{
Diagenesis of the sandstrones in Rift \\ Tectonossequence of Araripe Basin, NE Brazil \\ Ana Bárbara Sampaio Costa ${ }^{1 *}$, Valéria Centurion Córdoba ${ }^{1,2}$, \\ Emanuel Ferraz Jardim de Sá ${ }^{2}$, Claiton Marlon dos Santos Scherer ${ }^{3}$
}

RESUMO: A Bacia do Araripe é a mais extensa das bacias interiores do Nordeste do Brasil, apresentando história geológica mais complexa. $\mathrm{O}$ intervalo estudado corresponde às formaçôes Missão Velha e Abaiara, aflorantes na porção centro-oeste do Vale do Cariri. Visando subsidiar os estudos de diagênese, foi realizada uma análise faciológica que permitiu identificar dez fácies sedimentares, individualizadas, consoantes às diferentes litologias e principais estruturas sedimentares. O estudo petrográfico permitiu classificar os litótipos como quartzarenitos, que apresentam arcabouço rico em gráos de quartzo, feldspatos e fragmentos líticos e, subordinadamente, minerais pesados. A história diagenética mostrou-se bastante complexa, sendo caracterizada por uma grande variedade de fases que se sucederam durante os estágios de eo, meso e telodiagênese. O estágio eodiagenético é marcado pela infiltração mecânica de argilas e pelo ínicio da compactaçáo mecânica. O estágio mesodiagenético é caracterizado pelo final da compactaçáo mecânica, compactação química, crescimentos secundários de quartzo e feldspato, cimentação de calcita, dissolução, formação de caulinita autigênica, alteraçấo dos grãos para clorita e illita e precipitaçáo de minerais opacos. O estágio telodiagenético é evidenciado pela oxidação de grãos, matriz e cimentos presentes. Tais informaçôes permitiram realizar um estudo comparativo das formaçóes estudadas.

PALAVRAS-CHAVE: Bacia do Araripe; diagênese; Rifte.
ABSTRACT: The Araripe Basin is the largest interior basin in the Northeastern Brazil, with a more complex geological history. The studied interval corresponds to the Missão Velha and Abaiara formations, cropping out in the central-west Valley Cariri. To subsidize the studies of diagenesis and provenance, a facies analysis was performed which identified ten sedimentary facies according to different lithologies and main sedimentary structures. The petrographic study allowed classifying the lithotypes as quartzites, which present grains of quartz, feldspars and rock fragment sand, subordinately, heavy minerals. The diagenetic history was characterized by a variety of phases that occured during the stages of eo-, meso- and telodiagenesis. The eodiagenetic stage is marked by mechanical infiltration of clays and the beggining of mechanical compaction. The mesodiagenetic stage is characterized by the end of mechanical compaction, chemical compaction, quartz and feldspar overgrowths, calcite cementation, dissolution, authigenic kaolinite formation, alteration of grains to chlorite and illite, and the precipitation of opaque minerals. Telodiagenetic stage is evidenced by the oxidation of grains, matrix and cement present. This information allowed a comparative study of the formations.

KEYWORDS: Araripe Basin; diagenesis; Rift.

\footnotetext{
${ }^{1}$ Programa de Pós-Graduação em Geodinâmica e Geofísica, Universidade Federal do Rio Grande do Norte - UFRN, Natal (RN), Brasil. E-mails: anabarbarasampaio@gmail.com; valeria.geo@ufrnet.br

${ }^{2}$ Laboratório de Geologia e Geofísica do Petróleo, Centro de Ciências Exatas e da Terra, Departamento de Geologia, Universidade Federal do Rio Grande do Norte UFRN, Natal (RN), Brasil.E-mail:emanuel@ccet.ufrn.br

${ }^{3}$ Instituto de Geociências, Universidade Federal do Rio Grande do Sul - URGS, Porto Alegre (RS), Brasil. E-mail: claiton.scherer@ufgs.br

*Autor correspondente

Manuscrito ID: 30117. Recebido em: 09/05/2014. Aprovado em: 22/08/2014.
} 


\section{INTRODUÇÃO}

A diagênese refere-se a um conjunto de condiçôes físicas e químicas que controlam os processos atuantes nos sedimentos depositados, nos depósitos residuais e em todos os tipos de rochas presentes na superfície da crosta terrestre e nos primeiros milhares de metros de profundidade (De Ros 2001). É composta por três estágios distintos denominados de eo, meso e telodiagênese (Choquette \& Pray 1970, Schmidt et al. 1979). A eodiagênese ocorre desde a superfície até profundidades em torno de $2 \mathrm{~km} \mathrm{e}$ a uma temperatura de $70^{\circ} \mathrm{C}$ (Morad et al. 2000). A mesodiagênese subdivide-se em rasa e profunda. A rasa engloba profundidades compreendidas entre 2 e $3 \mathrm{~km}$ e as temperaturas oscilam entre 70 e $100^{\circ} \mathrm{C}$ (Morad et al. 2000). Nessa fase, os fluidos diagenéticos são modificados pelas reações com os minerais e circulam por compactação. A mesodiagênese profunda integra profundidades superiores a $3 \mathrm{~km}$ e temperaturas acima de $100^{\circ} \mathrm{C}$ (Morad et al. 2000). Por fim, a telodiagênese é caracterizada pelos eventos ocorridos durante a exposiçáo das rochas às condiçóes superfíciais, seja por soerguimento, erosáo ou por infiltração profunda de águas meteóricas (Morad et al. 2000).

O presente trabalho pretende apresentar os resultados obtidos a partir de um estudo diagenético comparativo conduzido em arenitos depositados durante a fase rifte na Bacia do Araripe; ilustrando assim uma proposta de sequência evolutiva dos eventos diagenéticos, discriminado-os de acordo com cada unidade litoestratigráfica pertencente a esse estágio tectônico rifte. Para tal, procedeu-se a seguinte ordem de atividades: (1) identificação, por meio da confecção e análise de seçóes colunares, das diferentes fácies e associaçôes de fácies, com a interpretação dos sistemas deposicionais característicos da seção inferior e superior da Formação Missão Velha (sensu Aquino 2009) e da Formação Abaiara; (2) realização de um estudo petrográfico enfatizando os aspectos texturais e composicionais das rochas analisadas para, por fim, classificá-las segundo as nomenclaturas usuais; e (3) realização de uma análise diagenética detalhada, identificando os processos que atuaram em cada fase específica, com o objetivo de, ao final, estabelecer uma história evolutiva destes eventos.

A Bacia do Araripe é a mais complexa das bacias interiores do Nordeste do Brasil e a sua ocorrência estende-se desde a Chapada do Araripe até o Vale do Cariri, perfazendo um total de 9 mil km² (Assine 1992). Os afloramentos investigados localizam-se em uma regiáo situada no Vale do Cariri, mais concretamente no sudeste do Estado do Ceará, a norte da cidade de Brejo Santo. Na sua porção central, situa-se a cidade de Abaiara e nas áreas circundantes estão as cidades de Missão Velha (oeste) e Milagres (norte) (Fig. 1).

\section{GEOLOGIA REGIONAL}

A Bacia do Araripe, juntamente com outros grábens e semigrábens de menor porte, como Iguatu, Icó, Lavras da Mangabeira e outras (Castro \& Castelo Branco 1999), constituem um conjunto de bacias interiores do Nordeste brasileiro, que se encontram alinhadas segundo o Trend Cariri-Potiguar (Matos 1992, 1999).

A origem dessas bacias está diretamente ligada a esforços tectônicos, associados ao rifteamento que moldou a atual margem continental, em consequência da separação das placas Sul-americana e Africana, durante o Eocretáceo. Utilizando um modelo simples, Matos (1992) sugere uma evolução tectônica para as bacias do tipo rifte do Vale do Cariri, como resultado de uma distensão NW-SE que reativou uma zona de cisalhamento sigmoidal de idade neoproterozoica. Esse mesmo autor afirma que, de forma genérica, essas bacias são constituídas por semigrábens com geometrias variáveis, com mergulho para SE. Françolin et al. (1994) propóem uma evolução tectônica mais complexa. Para tais autores, as bacias do tipo rifte do Vale do Cariri sofreram um deslocamento lateral E-W ao longo da Falha de Malta. A forma, localização e empilhamento estratigráfico dessas bacias, segundo esses autores, estariam fortemente controlados pelos lineamentos regionais pré-existentes do embasamento pré-cambriano na Província Borborema.

Segundo Assine (2007), a história evolutiva da Bacia do Araripe, recorrendo ao seu registro estratigráfico, pode ser dividida em quatro unidades genéticas: (1) Sequência Paleozoica; (2) Supersequência Pré-Rifte; (3) Supersequência Rifte; e (4) Supersequência Pós-Rifte. A seção inferior do empilhamento estratigráfico, correspondente à Sequência Paleozoica, é caracterizada por litótipos enquadrados litostratigraficamente na Formação Mauriti. Sobreposta, através de uma discordância regional, encontra-se a Supersequência Pré-Rifte Neojurassica (Andar Dom João), representada pela Formação Brejo Santo. A Supersequência Rifte engloba as formaçóes Missão Velha (Andar Dom João) e Abaiara (Andares Rio da Serra e Aratu). Por fim, a Supersequência Pós-Rifte é composta pelas formaçóes Rio da Batateira, Santana, Araripina e Exu, que cronoestratigraficamente se estende do Aptiano ao Cenomaniano. A formação Rio da Batateira representa depósitos flúvio-lacustres que se dispuseram preenchendo depressôes resultantes de eventos tectônicos pretéritos (Ponte \& Ponte Filho 1996). Gradualmente, a sedimentação passou a ser lacustre, originando as fácies carbonático-argilosas do Membro Crato, unidade basal da Formação Santana (Ponte \& Ponte Filho 1996). Uma ingressão marinha foi responsável pela deposição de fácies evaporíticas, correspondentes às Camadas Ipubi, e de fácies areno-argilosas de ambiente marinho raso, englobadas no Membro 

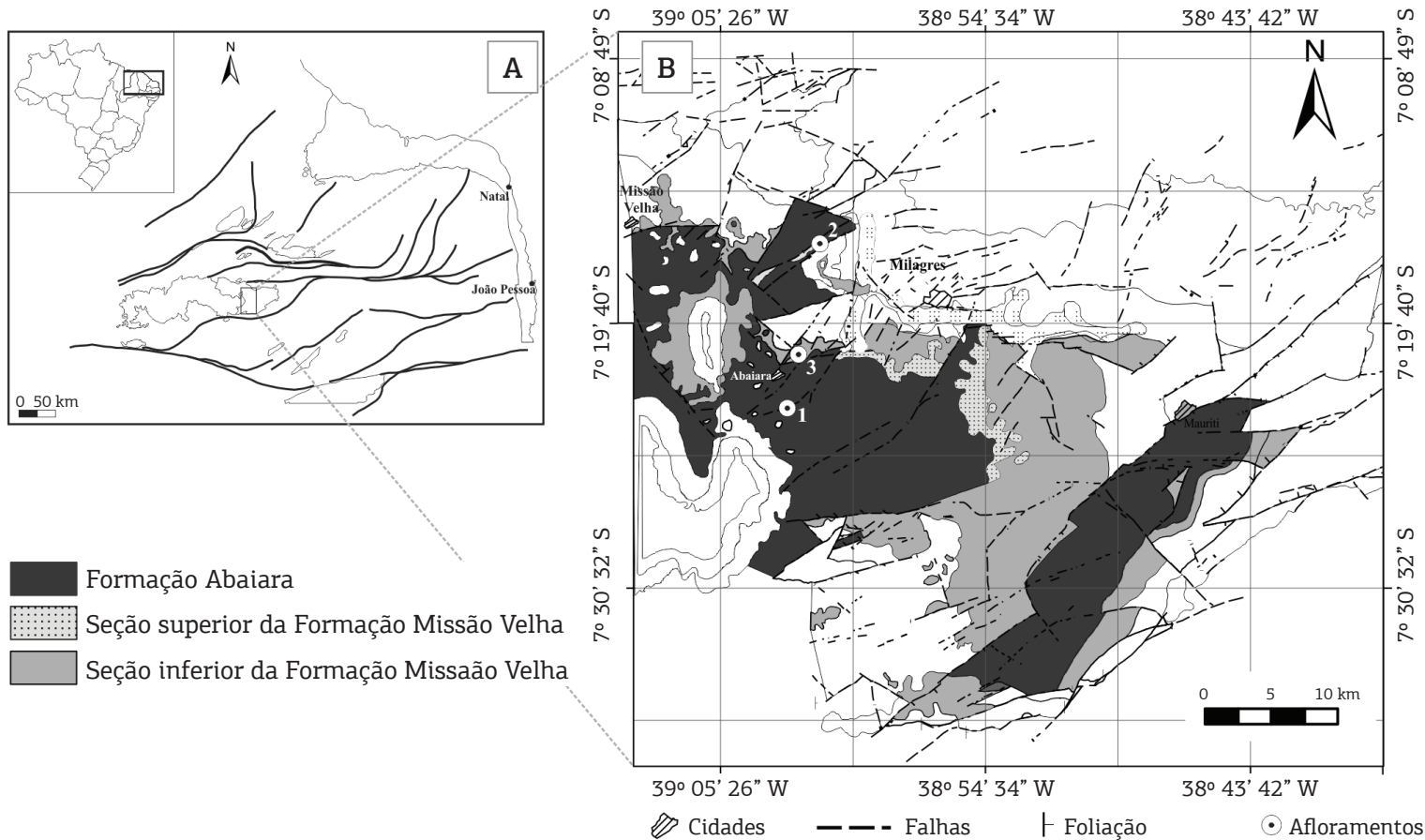

Figura 1. (A) Mapa de localização da Bacia do Araripe (modificado do Projeto Bacias Interiores (UFRN/PETROBRAS/ ANP); (B) Mapa geológico com a posição dos afloramentos estudados na porção Centro-Oeste da Bacia do Araripe (modificado de Scherer et al. 2014).

Romualdo, ambos pertencentes à Formação Santana. Acima, estratigraficamante, ocorrem fácies terrígenas de ambiente transicional litorâneo da Formação Araripina (Assine 2007). Na transição Albiano-Cenomaniano teve início a fase regressiva, que impulsionou a sedimentação fluvial da bacia, representada por rochas siliciclásticas da Formação Exu (Ponte \& Ponte Filho 1996). Durante esse período, ocorreram pulsos tectônicos tardios que reativaram falhamentos e promoveram o basculamento de blocos.

Aquino (2009) e Cardoso (2010) utilizaram o termo "tectonossequência" em lugar de "sequência" e "supersequência”, denominando de Tectonossequência de Sinéclise Paleozoica a Sequência Paleozoica, de Tectonossequência Jurássica a Supersequência Pré-Rifte e de tectonossequências Pós-Rifte I e Pós-Rifte II, as sequências homônimas, englobadas na Supersequência Pós-Rifte.

Além disso, estudos realizados por Aquino (2009) permitiram a subdivisão da Formação Missão Velha em duas seçóes, uma inferior e outra superior, separadas por um nível conglomerático com troncos de fósseis retrabalhados. Assim, a Tectonossequência Jurássica passou a ser representada pela formações Brejo Santo e pela seção inferior da Formação Missão Velha, ao passo que a seção superior dessa formação, que foi reposicionada no
Andar Rio da Serra, passou a integrar, juntamente com a Formação Abaiara, a Tectonossequência Rifte.

Para Cardoso (2010), a Tectonossequência Rifte é caracterizada por dois tratos de sistemas tectônicos, os tratos de Início de Rifte e de Clímax de Rifte. O Trato de Sistemas de Início de Rifte é composto pela seção inferior da Formação Missão Velha, e é superposta à Formação Brejo Santo através de uma discordância designada de Pré-Rio da Serra. O Trato de Sistemas de Clímax de Rifte é constituído por rochas da seção superior da Formação Missão Velha e pela Formação Abaiara.

Estudos mais recentes, levados a cabo por Scherer et al. (2012, 2014), compartimentaram a seção Juro-Neocomiana em quatro sequências deposicionais, denominadas de sequências I a IV. As sequências I e II, equivalentes à Formação Brejo Santo e à porção inferior da Formação Missão Velha, respectivamente, foram interpretadas por aqueles autores como depositadas nos estágios iniciais do rifteamento da bacia. Ainda segundo tais autores, a Sequência III, correspondente à seção superior da Formação Missão Velha, relaciona-se ao início da implantação de altos e grábens internos juntamente a uma importante reorganizaçáo estrutural. A Sequência IV, por sua vez, foi acumulada em um sistema de semigráben bem definido. 
A Fig. 2 apresenta um sumário com a proposta estratigráfica adotada neste trabalho, a qual incorpora conceitos apresentados nas proposições anteriores.

\section{FÁCIES E SISTEMAS DEPOSICIONAIS}

A seção inferior da Formação Missão Velha é composta predominantemente por arenitos (fácies Aa, Ap, Ah, Aba, Amo e Am; Tab. 1 e Fig. 3), no entanto, em alguns afloramentos, a exemplo do afloramento 2 (Fig. 4), estão presentes alguns níveis centimétricos de pelitos (fácies Pm; Tab. 1). Nos afloramentos estudados ocorrem arenitos grossos a conglomeráticos, arenitos médios e ainda arenitos finos a muito finos. Os arenitos grossos a conglomeráticos manifestamse de forma subordinada, sendo pobremente selecionados e contêm clastos de argila, seixos de quartzo, seixos de feldspatos, além de troncos silicificados. As estruturas sedimentares presentes estão bem definidas, sendo representadas por acamamento maciço (fácies Am; Fig. 3A), estratificações plano-paralelas (fácies $\mathrm{Ah}$ ), cruzadas de baixo ângulo (fácies Aba), acanaladas (fácies Aa; Fig. 3B) e tabulares (fácies Ap), as quais podem apresentar-se fluidizadas. $\mathrm{Na}$ base dos sets ou dispersos nos planos de estratificação, é possível encontrar clastos argilosos, seixos de quartzo, seixos de felspatos e troncos de madeira silicificados (afloramento 2, Fig. 4). Em alguns desses arenitos é possível observar granodecrescência, com passagem de conglomerados na base, para arenitos muito grossos no topo, cuja espessura dos estratos varia de 1,30 a $5 \mathrm{~m}$. Os arenitos médios predominam e exibem grãos subangulosos a subarredondados e são moderadamente a pobremente selecionados. Os mesmos exibem estratificaçôes cruzadas tabulares planares (fácies Ap), acanaladas (fácies Aa), de baixo ângulo (fácies Aba) e, por vezes, apresentam estrutura maciça, com seixos e grânulos de quartzo dispersos ao longo do plano de estratificação (afloramento 3, Fig. 4). Já os arenitos finos a muito finos apresentam-se bem selecionados, por vezes maciços (fácies Am) ou com estruturas sedimentares caracterizadas por estratificaçóes cruzadas acanaladas (fácies Aa; Fig. 3C), tabulares (fácies Ap) e de marcas onduladas (fácies Amo; algumas incipientes).

As estruturas sedimentares presentes nas fácies areníticas que indicam fluxos unidireccionais, além da ocorrência de estratos amalgamados ou se sucedendo evidenciando um ligeiramento afinamento textural para o topo, permitiu definir uma associação de fácies de canais fluviais arenosos, levemente sinuosos. Intercalando essa associação ocorrem, de forma esporádica, níveis centimétricos de pelitos e arenitos finos, que foram englobados em uma segunda associação de fácies, referida como associação de depósitos externos ao canal. A ocorrência marcante da associação de fácies de canais fluviais arenosos um pouco sinuosos, a baixa frequência de pelitos e as características diagnósticas de cada fácies permitem interpretar que, no início da deposição da Tectonossequência Rifte, o cenário deposicional era representado por sistemas fluviais entrelaçados levemente sinuosos (Fig. 5).

A seção superior da Formação Missão Velha é formada por espessos pacotes areníticos amalgamados (fácies Aa, Ap, Aba e Am; Tab. 1). Na base dessa seção, separando-a da seção inferior da Formação Missão Velha e delimitando a discordância interna a essa formação, como já documentado por Aquino (2009) e Cardoso (2010), ocorre um nível conglomerático matriz-sustentado, formado por seixos de quartzo, seixos de feldspatos, além de arenitos da seção inferior (fácies Cmm; afloramento 2, 28 m; Fig. 4). Os arenitos da seção superior da Formação Missão Velha apresentam, em sua maioria, granulometria grossa a conglomerática, são pobremente selecionados e contêm grãos angulosos a subangulosos, representados principalmente por quartzo e feldspatos; troncos de madeira podem estar presentes. As estruturas sedimentares predominantes são as estratificaçôes cruzadas acanaladas (fácies Aa; Fig. 3C) e raras estratificaçóes cruzadas de baixo ângulo (fácies $\mathrm{Aba}$ ). Dispersos nos planos da estratificação ou na base dos sets, é possível visualizar restos de troncos de madeira (Fig. 3D), clastos de argila, seixos de feldspatos e grânulos e seixos de quartzo. Ocorrem também, de forma subordinada, arenitos finos a médios, pobremente a moderadamente selecionados, com grânulos de quartzo, que podem apresentar-se maciços (fácies Am) ou conter estratificações cruzadas de baixo ângulo (fácies Aba), acanaladas (fácies Aa) e tabulares (fácies Ap), compondo sets de 10 a $40 \mathrm{~cm}$ (Fig. 4).

A presença de fácies areníticas com estratificaçôes cruzadas tabulares que indicam a deposição de barras transversais, além do aumento granulométrico significante quando comparado com a seção inferior da Formação Missão Velha, permite interpretar que tais fácies, juntamente com os conglomerados que ocorrem na base dos ciclos, compóem uma associação de fácies de canais fluviais arenosos e cascalhosos de um sistema fluvial entrelaçado típico (Fig. 5).

$\mathrm{Na}$ Formação Abaiara predominam rochas de granulometria mais fina como siltitos e argilitos intercalados a arenitos (fácies Aa, Amo, Aba, Ah, Am, Ad, Pl e Pm; Tab. 1). Os pelitos da Formação Abaiara apresentam cor vermelha, verde e cinza, ocorrendo associados a arenitos finos a médios que podem apresentar estrutura maciça, e laminaçóes plano-paralelas ou cruzadas de marcas onduladas (afloramento 1; Fig. 4). Ocorrem ainda arenitos médios a grossos e também arenitos finos. Os arenitos médios a grossos variam de pobremente a bem selecionados e podem conter grânulos e seixos de quartzo. As estruturas 


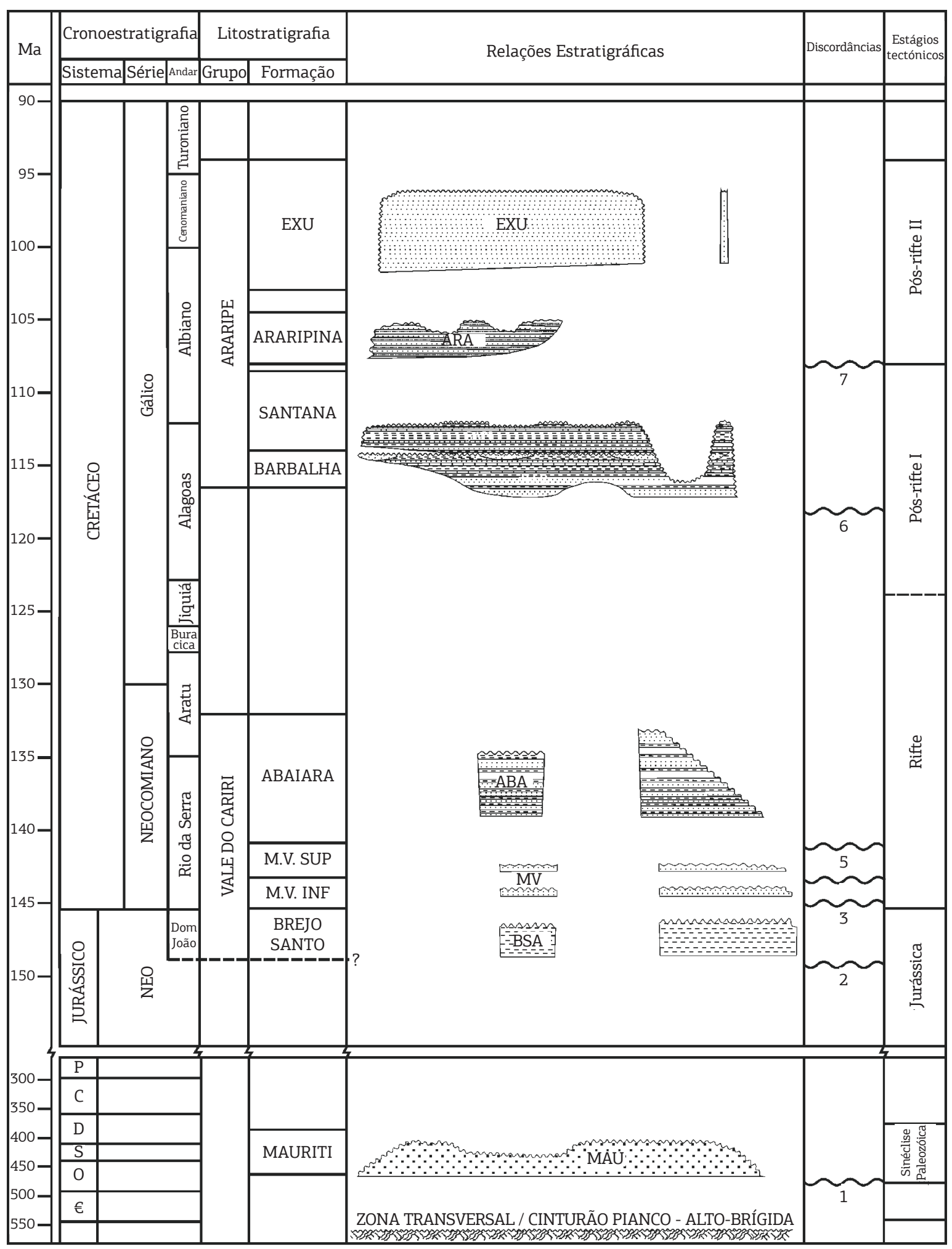

Figura 2. Proposta estratigráfica com a descrição das unidades litostratigráficas arranjadas segundo os diferentes estágios tectônicos da Bacia do Araripe (compilado de Assine 2009, Aquino 2009, Garcia 2009, Cardoso 2010). Discordâncias: (1) Pré-Siluriana; (2) Pré-Dom João; (3) Pré-Rio da Serra; (4) Intra-Rio da Serra I; (5) Intra-Rio da Serra II; (6) Pré-Alagoas; (7) Pré-Albiano superior. 
Tabela 1. Fácies deposicionais descritas para os arenitos estudados na Bacia do Araripe

\begin{tabular}{|c|c|c|c|}
\hline Fácies & Litologia & Estruturas Sedimentares & Interpretação (Miall 1996) \\
\hline $\mathrm{Cmm}$ & $\begin{array}{l}\text { Conglomerados matriz-sustentados } \\
\text { com seixos de quartzo e seixos de } \\
\text { feldspatos, angulosos a subangulosos }\end{array}$ & $\begin{array}{l}\text { Estrutura maciça ou } \\
\text { gradação incipiente }\end{array}$ & $\begin{array}{l}\text { Depósitos gerados por } \\
\text { fluxo de detritos plásticos }\end{array}$ \\
\hline Aa & $\begin{array}{l}\text { Arenitos finos a médios, } \\
\text { bem selecionados }\end{array}$ & $\begin{array}{l}\text { Sets de estratificações } \\
\text { cruzadas acanaladas }\end{array}$ & $\begin{array}{l}\text { Dunas arenosas 3D, cristas } \\
\text { sinuosas a linguóides, fluxos } \\
\text { trativos unidirecionais, } \\
\text { regime de fluxo inferior }\end{array}$ \\
\hline Ap & $\begin{array}{c}\text { AArenitos finos a grossos, } \\
\text { moderadamente a bem selecionados, } \\
\text { podendo apresentar grânulos } \\
\text { e seixos de quartzo dispersos } \\
\text { nos planos da estratificação ou } \\
\text { concentrados na base das camadas }\end{array}$ & $\begin{array}{l}\text { Estratificações cruzadas } \\
\text { tabulares dispostas em sets de } \\
10 \text { a } 30 \mathrm{~cm} \text { de espessura. } \\
\text { Estratificações deformadas formando } \\
\text { estratos cruzados recumbentes }\end{array}$ & $\begin{array}{l}\text { Dunas transversais } 2 \mathrm{D}, \\
\text { fluxos trativos unidirecionais, } \\
\text { regime de fluxo inferior }\end{array}$ \\
\hline Aba & $\begin{array}{l}\text { Arenitos finos a conglomeráticos, } \\
\text { moderadamente selecionados, } \\
\text { com grânulos e seixos de quartzo, } \\
\text { seixos de feldspatos dispersos } \\
\text { nos planos de estratificação }\end{array}$ & $\begin{array}{l}\text { Estratificações cruzadas de baixo } \\
\text { ângulo dispostas em sets }\end{array}$ & $\begin{array}{l}\text { Preenchimento de suaves depressões, } \\
\text { dunas atenuadas, antidunas }\end{array}$ \\
\hline Ah & $\begin{array}{l}\text { Arenitos muito } \\
\text { finos a grossos }\end{array}$ & $\begin{array}{c}\text { Laminação e estratificação } \\
\text { plano-paralela, lineação por partição }\end{array}$ & $\begin{array}{l}\text { Formas de leito plano, } \\
\text { regime de fluxo superior/crítico }\end{array}$ \\
\hline Am & $\begin{array}{l}\text { Arenitos finos a médios, } \\
\text { bem selecionados. Por vezes, } \\
\text { ocorrem grânulos e clastos de } \\
\text { caliche e/ou clastos argilosos } \\
\text { na base das camadas }\end{array}$ & $\begin{array}{l}\text { Estrutura } \\
\text { maciça }\end{array}$ & $\begin{array}{l}\text { Depósitos de fluxos } \\
\text { hiperconcentrados fluidizados } \\
\text { ou intensa bioturbação }\end{array}$ \\
\hline Ad & $\begin{array}{l}\text { Arenitos finos } \\
\text { a grossos }\end{array}$ & $\begin{array}{l}\text { Estratificações cruzadas tabulares, } \\
\text { planares, acanaladas ou sigmoidais } \\
\text { deformadas, formando estruturas } \\
\text { do tipo estratificação cruzada } \\
\text { recumbente ou dobras convolutas }\end{array}$ & $\begin{array}{l}\text { Fluidização e deformação plástica de } \\
\text { sedimentos previamente depositados }\end{array}$ \\
\hline $\mathrm{Pl}$ & $\begin{array}{l}\text { Pelitos (lamitos e argilitos) com } \\
\text { tons avermelhados ou esverdeados }\end{array}$ & $\begin{array}{l}\text { Delgadas laminações, laminações } \\
\text { cruzadas de marcas onduladas }\end{array}$ & $\begin{array}{c}\text { Assentamento gravitacional } \\
\text { de partículas em suspensão, } \\
\text { floculação de argilas, correntes fracas }\end{array}$ \\
\hline $\mathrm{Pm}$ & $\begin{array}{l}\text { Pelitos (lamitos e argilitos) } \\
\text { com tons avermelhados }\end{array}$ & $\begin{array}{l}\text { Estrutura } \\
\text { maciça }\end{array}$ & $\begin{array}{l}\text { Assentamento gravitacional } \\
\text { de partículas em suspensão }\end{array}$ \\
\hline
\end{tabular}

sedimentares presentes constituem estratificaçôes cruzadas acanaladas (fácies Aa), de baixo ângulo (fácies Aba), tabulares planares (fácies Ad) ou maciça (fácies Am); estruturas de fluidização (dobras convolutas; afloramento 1, 108 140 m; Fig. 4) podem estar presentes. Grânulos e seixos de quartzo são visíveis na base dos sets e ao longo do plano de estratificação. Ocorrem também arenitos finos que são bem selecionados, apresentam cor branca e exibem estratificaçôes cruzadas de baixo ângulo (fácies Aba), acanaladas de grande porte (fácies Aa), além de laminações plano-paralelas (fácies Ah), marcas onduladas incipientes (fácies Amo), marcas onduladas cavalgantes, laminaçóes deformadas com dobras e falhas sin-deposicionais (fácies Ad; Fig. 3E), além de estruturas de fluidização e bioturbação (Fig. 4).

As fácies descritas para a Formação Abaiara são, dentre as descritas nas demais unidades, as mais variadas, indicando assim uma grande diversidade de processos sedimentares e associaçôes de fácies. Foram identificadas três associaçôes de fácies, conforme já proposto por Scherer et al. (2014): (1) associação de fácies de canais fluviais sinuosos; (2) associação de fácies de planície deltaica; e (3) associação de fácies de frente deltaica e prodelta. Tais associaçóes permitem interpretar que, ao final dessa tectonossequência, o cenário deposicional passou a ser caracterizado pela implantação de um amplo sistema deltaico com todas as suas porçôes fisiográficas bem representadas, associado a um sistema fluvial meandrante (Fig. 5).

\section{ANÁLISE PETROGRÁFICA}

Os arenitos da seção inferior da Formação Missão Velha possuem granulometria areia fina a média, com grãos muito bem a moderadamente selecionados, arredondamento variável, de subangular a subarredondado, e esfericidade baixa (vide Fig. 6A no próximo item). Os contatos retos são os 

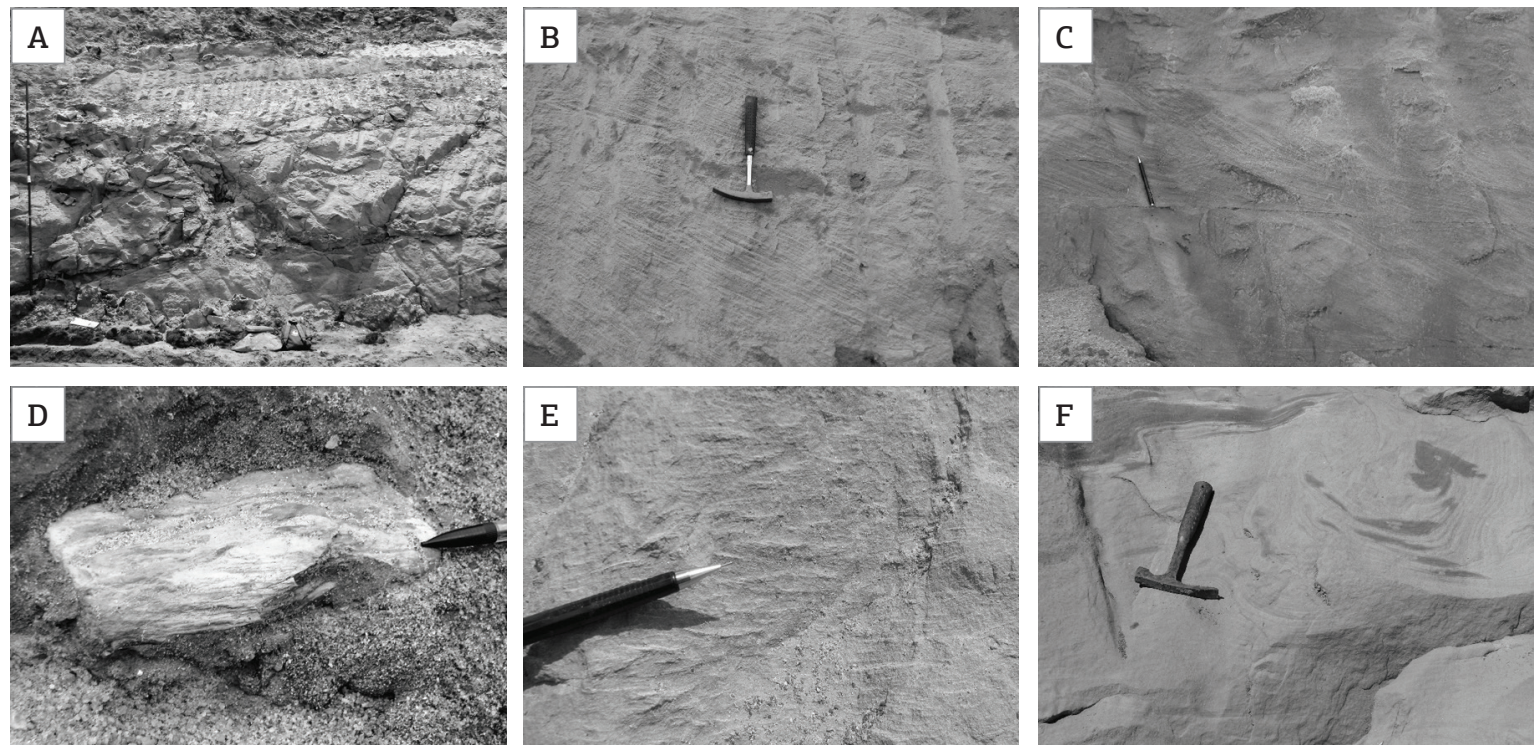

Figura 3. Fotografias ilustrando as fácies deposicionais descritas para os arenitos da Formação Missão Velha: (A) Fácies Am, apresentando estruturas maciças, seção inferior da Formação Missão Velha, Afloramento 2; (B) Fácies Aa, representando estratificações acanaladas de médio porte, seção inferior da Formação Missão Velha, Afloramento 3; (C) Fácies Aa, estratificações cruzadas acanaladas de pequeno porte, seção superior da Formação Missão Velha, Afloramento 2; (D) Madeira fóssil, seção superior da Formação Missão Velha; (E) Marcas onduladas incipientes da fácies Amo, Formação Abaiara e, (F) Fácies Ad denotando a presença de estruturas de fluidização, Formação Abaiara..

que ocorrem com maior frequência, seguidos dos contatos côncavo-convexos, o que confere à rocha um empacotamento normal a fechado. As rochas são texturalmente maturas. Com relação à maturidade mineralógica, graças à presença de mais de $95 \%$ de quartzo e chert, tais rochas são classificadas, em geral, como supermaturas. A composição mineralógica é predominantemente representada por grãos de quartzo e, de forma subordinada, por feldspatos e fragmentos de rocha. Minerais pesados como zircão, esfeno, estaurolita e turmalina, assim como minerais pertencentes ao grupo dos filossilicatos como muscovita, biotita e clorita também foram identificados. A matriz é constituída essencialmente por argilominerais infiltrados e pseudomatriz. Os cimentos são representados pelo tipo ferruginoso, calcita, crescimentos secundários de quartzo e feldspato, e/ou por argilominerais autigênicos como a caulinita.

Segundo a classificação de Folk (1968) as rochas dessa unidade são nomeadas como quartzarenito e, localmente, subarcóseo.

Os arenitos da seção superior da Formação Missão Velha apresentam granulometria que varia desde areia muito fina a muito grossa, são moderada a pobremente selecionados, com grãos angulosos a subangulosos e com esfericidade baixa (vide Fig. 6D no próximo item). O empacotamento é do tipo frouxo, com o predomínio de contatos flutuantes, sendo comuns os contatos pontuais e raros os côncavo-convexos. Texturalmente, tais rochas são consideradas submaturas. A maturidade mineralógica é elevada, com o somatório de quartzo e chert excedendo os 95\% e, como tal, as rochas dessa seção classificam-se como supermaturas. Composicionalmente, tais rochas apresentam um predomínio de grãos de quartzo, ocorrendo ainda feldspatos e fragmentos de rocha. Minerais pesados como a turmalina e zircão estão presentes, assim como muscovita, biotita e clorita. A matriz é do tipo argila infiltrada e pseudomatriz. O cimento é formado por crescimentos secundários de quartzo e por argilominerais autigênicos como a caulinita.

Ainda segundo a classificação de Folk (1968), as rochas dessa unidade foram enquadradas como quartzarenito e, localmente, subarcóseo.

A Formação Abaiara é composta por arenitos muito finos a médios, com grãos bem a muito bem selecionados, predominantemente angulosos a subarredondados, com esfericidade baixa. O contato entre os grãos do arcabouço é dominantemente reto, sendo comum o côncavo-convexo, o que confere às rochas dessa formação um empacotamento normal (vide Fig. 6F no próximo item). Texturalmente, as rochas dessa unidade são classificadas como maturas. A maturidade mineralógica é elevada, definida como supermatura, em virtude da percentagem do somatário de quartzo mais chert ser 


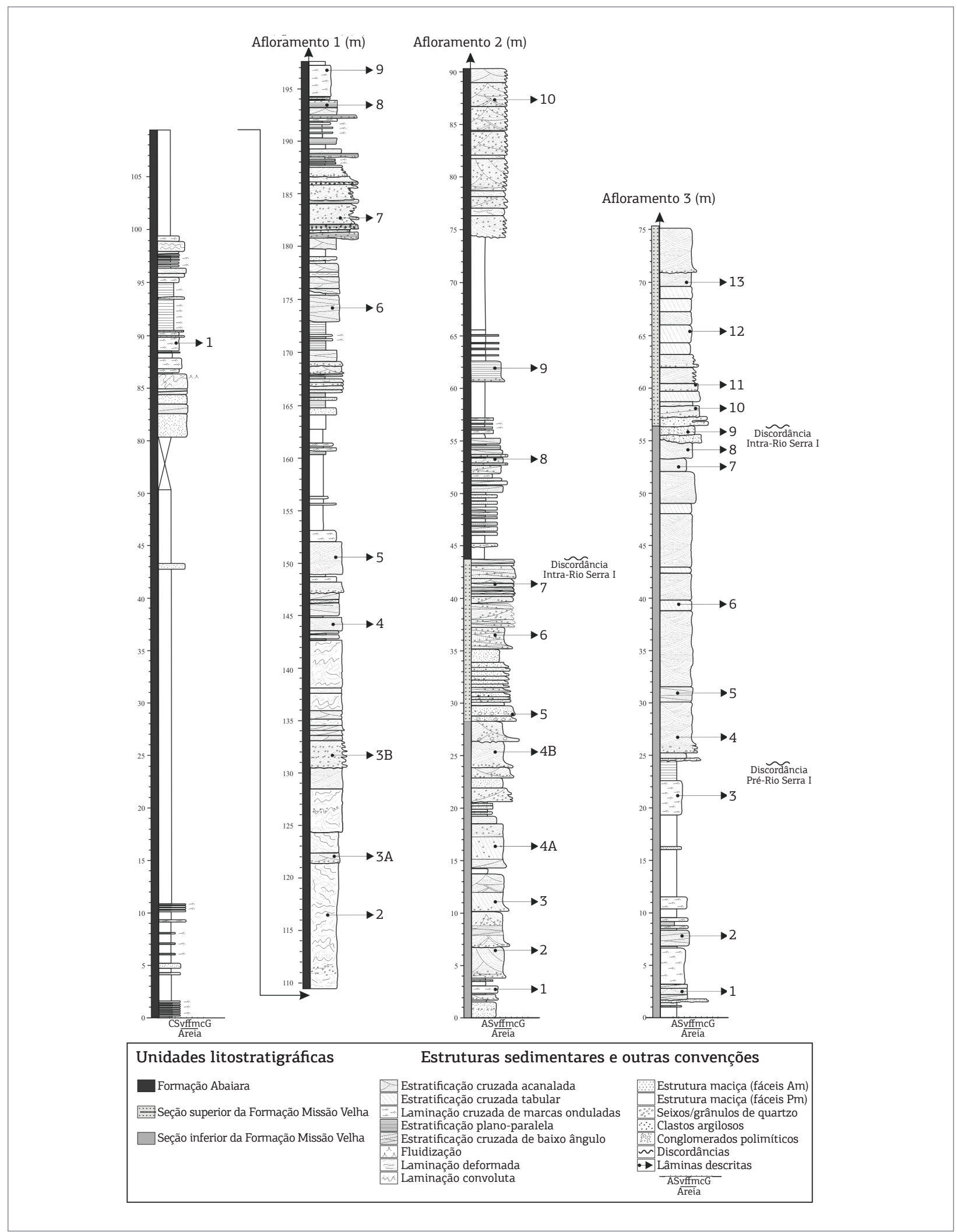

Figura 4. Seções colunares dos afloramentos adotados com referência para o estudo de fácies, associação de fácies, e para a análise diagenética (modificado de Aquino 2009 e Scherer et al. 2014). A numeração dos afloramentos segue a apresentada em Scherer et al. (2014). 
Tabela 2. Descrição e interpretação de fácies e cenários deposicionais propostos para a Tectonossequência Rifte na Bacia do Araripe.

\begin{tabular}{|c|c|c|c|c|c|c|c|}
\hline & $\begin{array}{l}\text { Associação } \\
\text { de fácies }\end{array}$ & Fácies & Descrição & Interpretação & $\begin{array}{c}\text { Sistema } \\
\text { Deposicional }\end{array}$ & $\begin{array}{c}\text { Cenário } \\
\text { deposicional }\end{array}$ \\
\hline \multirow{6}{*}{ 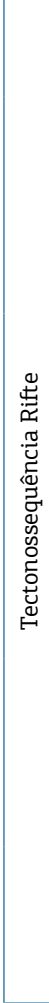 } & \multirow{3}{*}{ 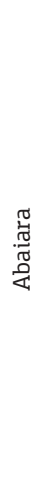 } & $\begin{array}{l}\text { Canais } \\
\text { fluviais } \\
\text { sinuosos }\end{array}$ & $\begin{array}{l}\mathrm{Aa}, \mathrm{Ad}, \\
\mathrm{Pm}^{*}\end{array}$ & $\begin{array}{l}\text { Corpos areníticos amalgamados limitados por } \\
\text { superfícies erosivas côncavas que compõem } \\
\text { sucessões com granodecrescência ascendente. }\end{array}$ & $\begin{array}{c}\text { Depósitos de } \\
\text { barra em pontual }\end{array}$ & \multirow{3}{*}{$\begin{array}{l}\text { - Sistema } \\
\text { Fluvial } \\
\text { Meandrante } \\
\text { - Sistema } \\
\text { Deltaico }\end{array}$} & \multirow[t]{3}{*}{ A } \\
\hline & & $\begin{array}{l}\text { Planície } \\
\text { Deltaica }\end{array}$ & $\begin{array}{l}\text { Aa, Aba, } \\
\text { Amo, Ah, } \\
\text { Am, Ad, } \\
\text { Pm, Pl }\end{array}$ & $\begin{array}{l}\text { Corpos areníticos com granodecrescência } \\
\text { ascendente, com espessura } 1,5 \text { a } 5 \mathrm{~m} \text {. Na } \\
\text { base ocorrem arenitos com estratificação } \\
\text { cruzada que passam ao topo para arenitos } \\
\text { mais finos com laminações de marcas } \\
\text { onduladas. Por vezes, finalizando os ciclos, } \\
\text { ocorrem pacotes de pelitos maciços. }\end{array}$ & $\begin{array}{l}\text { Canais fluviais } \\
\text { de baixa } \\
\text { sinuosidade de } \\
\text { planície deltaica }\end{array}$ & & \\
\hline & & $\begin{array}{l}\text { Frente } \\
\text { deltaica/ } \\
\text { Prodelta } \\
\text { proximal }\end{array}$ & $\begin{array}{l}\text { Aa, Amo, } \\
\text { Am, Ad, } \\
\text { Pm, Pl }\end{array}$ & $\begin{array}{l}\text { Corpos areníticos e pelíticos compondo } \\
\text { sucessões com granocrescência ascendente, } \\
\text { com espessura de até } 10 \mathrm{~m} \text {, iniciando com } \\
\text { pelitos de prodelta e culminando com } \\
\text { arenitos com feições deformacionais e } \\
\text { arenitos com estratificações cruzadas. }\end{array}$ & $\begin{array}{l}\text { Lobos deltaicos } \\
\text { progradacionais } \\
\text { dominados por } \\
\text { processos fluviais }\end{array}$ & & \\
\hline & 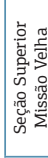 & $\begin{array}{l}\text { Canais } \\
\text { fluviais pouco } \\
\text { sinuosos } \\
\text { arenosos a } \\
\text { cascalhosos }\end{array}$ & $\begin{array}{l}\mathrm{Aa}, \mathrm{Ap} \\
\mathrm{Aba}, \mathrm{Am} \\
\mathrm{Cmm}^{*} \\
\mathrm{Pm}^{*}\end{array}$ & $\begin{array}{l}\text { Corpos areníticos com geometria em lençol, } \\
\text { amalgamados, limitados por superfícies } \\
\text { erosivas. Ocorrem, por vezes, camadas de } \\
\text { conglomerados de grânulos e seixos. }\end{array}$ & $\begin{array}{l}\text { Lags residuais de } \\
\text { fundo de canal } \\
\text { e barras fluviais } \\
\text { transversais } \\
\text { amalgamadas }\end{array}$ & $\begin{array}{c}\text { - Sistema } \\
\text { Fluvial } \\
\text { Entrelaçado }\end{array}$ & B \\
\hline & \multirow{2}{*}{ 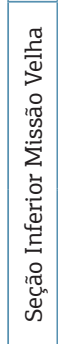 } & $\begin{array}{l}\text { Canais fluviais } \\
\text { arenosos, } \\
\text { levemente } \\
\text { sinuosos }\end{array}$ & $\begin{array}{l}\text { Aa, Aba, } \\
\text { Am, Ap, } \\
\quad \text { Ah }\end{array}$ & $\begin{array}{l}\text { Corpos areníticos com espessuras que } \\
\text { variam de } 0,2 \text { a } 2 \mathrm{~m} \text {, limitados por superfícies } \\
\text { erosivas, levemente côncavas, marcadas por } \\
\text { concentrações de grânulos e seixos de quartzo. } \\
\text { Apresentem padrão de granodecrescência } \\
\text { ascendente fracamente desenvolvido. }\end{array}$ & $\begin{array}{l}\text { Barras internas } \\
\text { ao canal fluvial, } \\
\text { transversais e } \\
\text { localmente em } \\
\text { pontal }\end{array}$ & \multirow{2}{*}{$\begin{array}{c}\text { - Sistema } \\
\text { Fluvial } \\
\text { Entrelaçado }\end{array}$} & \multirow[t]{2}{*}{ C } \\
\hline & & $\begin{array}{l}\text { Depósitos } \\
\text { externos aos } \\
\text { canais fluviais }\end{array}$ & $\begin{array}{l}\mathrm{Aa}^{*}, \mathrm{Am} \\
\mathrm{Amo}, \mathrm{Pm}\end{array}$ & $\begin{array}{l}\text { Corpos pelíticos intercalados com } \\
\text { níveis areníticos decimátricos, } \\
\text { com geometria tabular. }\end{array}$ & $\begin{array}{l}\text { Depósitos de } \\
\text { planície de } \\
\text { inundação e de } \\
\text { extravasamento } \\
\text { de canal }\end{array}$ & & \\
\hline
\end{tabular}

*Ocorrência local.
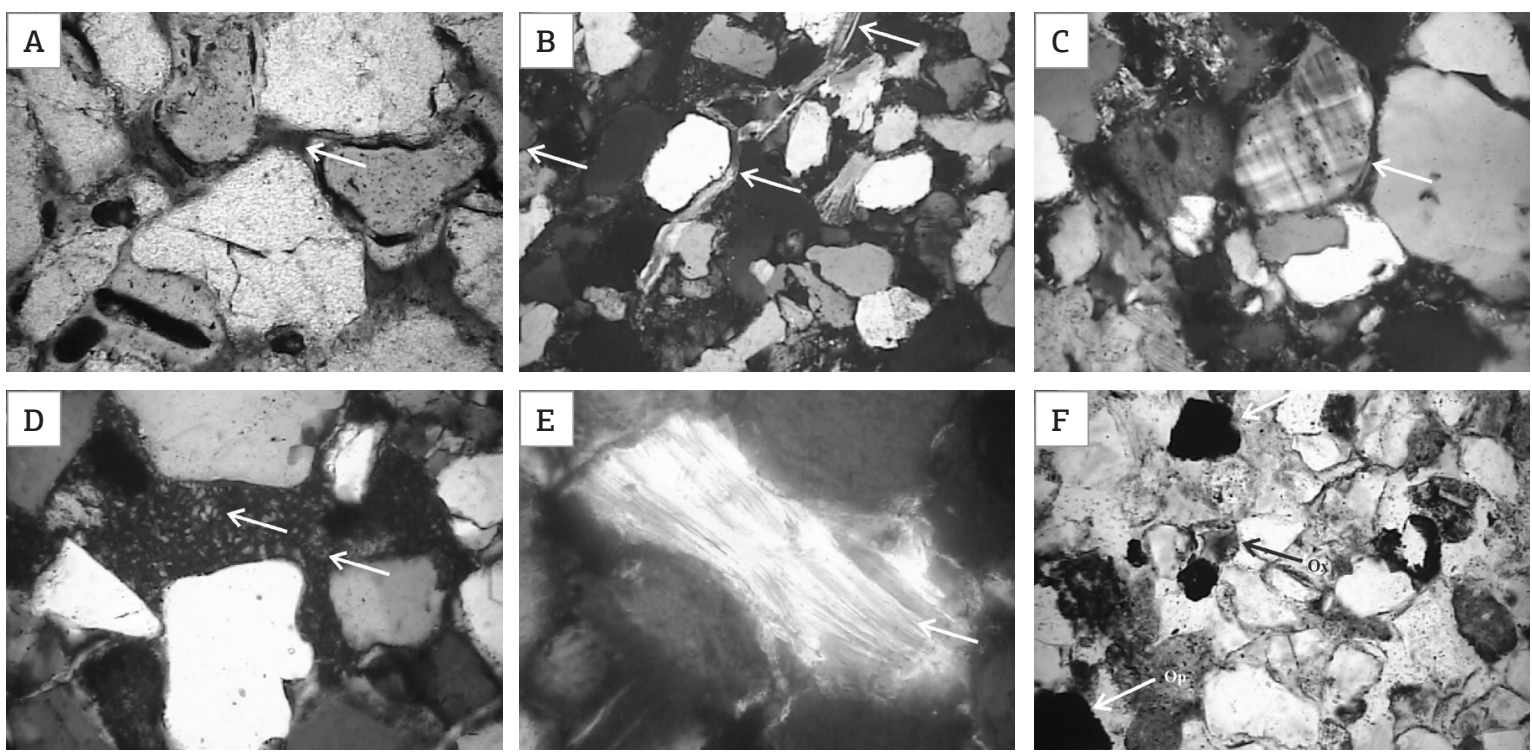

Figura 5. Fotomicrografias ilustrando os eventos diagenéticos dos arenitos estudados. (A) Infiltração mecânica de argilas (menisco de illita preenchendo as gargantas dos poros; seção inferior da Formação Missão Velha; nicóis paralelas); (B) Compactação mecânica e química (rearranjo textural das biotitas e contatos suturados; Formação Abaiara; nicóis cruzados); (C) Crescimentos secundários de feldspato (seção inferior da Formação Missão Velha; nicóis cruzados); (D) Formação de caulinita autigência exibindo estrutura embooklets (seção superior da Formação Missão Velha; nicóis cruzados); (E) Caulinização da muscovita (Formação Abaiara; nicóis cruzados); (F) Precipitação de minerais opacos (Op) e oxidação de minerais (Ox; Formação Abaiara; nicóis paralelas). 
superior a 95\%. Na análise composicional, verificou-se, tal como nas formaçôes anteriormente descritas, uma grande abundância em quartzo, feldspatos e fragmentos de rocha, contudo, minerais mais resistentes como o zircão, esfeno, espídoto e turmalina são frequentes. Biotita, muscovita e clorita estão também presentes. A matriz é do tipo argila infiltrada e pseudomatriz, ao passo que o cimento pode ser precipitado sobre a forma de argilominerais (caulinita) ou ocorrer como crescimentos secundários de quartzo.

As rochas dessa unidade foram classificadas segundo Folk (1968) como quartzarenito.

\section{PROCESSOS DIAGENÉTICOS E HISTÓRIA EVOLUTIVA}

\section{Considerações gerais}

Os arenitos estudados foram afetados diageneticamente por dez processos distintos. De acordo com a unidade litoestratigráfica estudada e as particularidades texturais e composicionais intrínsecas às fácies dessas unidades, alguns processos se mostraram mais ou menos atuantes, outros até mesmo ausentes. Com base na relação temporal entre esses eventos, foi possível estabelecer uma sequência evolutiva desde a eodiagênese até a telodiagênese, particularizada para cada formação estudada. Assim, os eventos diagenéticos caracterizados neste estudo integram a seguinte ordem de ocorrência: (1) infiltração mecânica de argilas; (2) compactação mecânica; (3) compactação química; (4) crescimentos secundários de quartzo e feldspato; (5) cimentação por calcita; (6) dissolução; (7) formação de caulinita autigênica; (8) alteração de grãos para argilominerais; (9) precipitação de minerais opacos; e (10) oxidação telodiagenética.

\section{Eodiagênese}

\section{Infiltração mecânica de argilas}

Os arenitos das formaçóes estudadas contêm argilominerais mecanicamente infiltrados sob a forma de cutículas (contínuas ou descontínuas), meniscos (pontes ou cristas) e agregados/massas floculadas; alguns exibem ainda textura de encolhimento (shrinkage). As cutículas mostram-se,

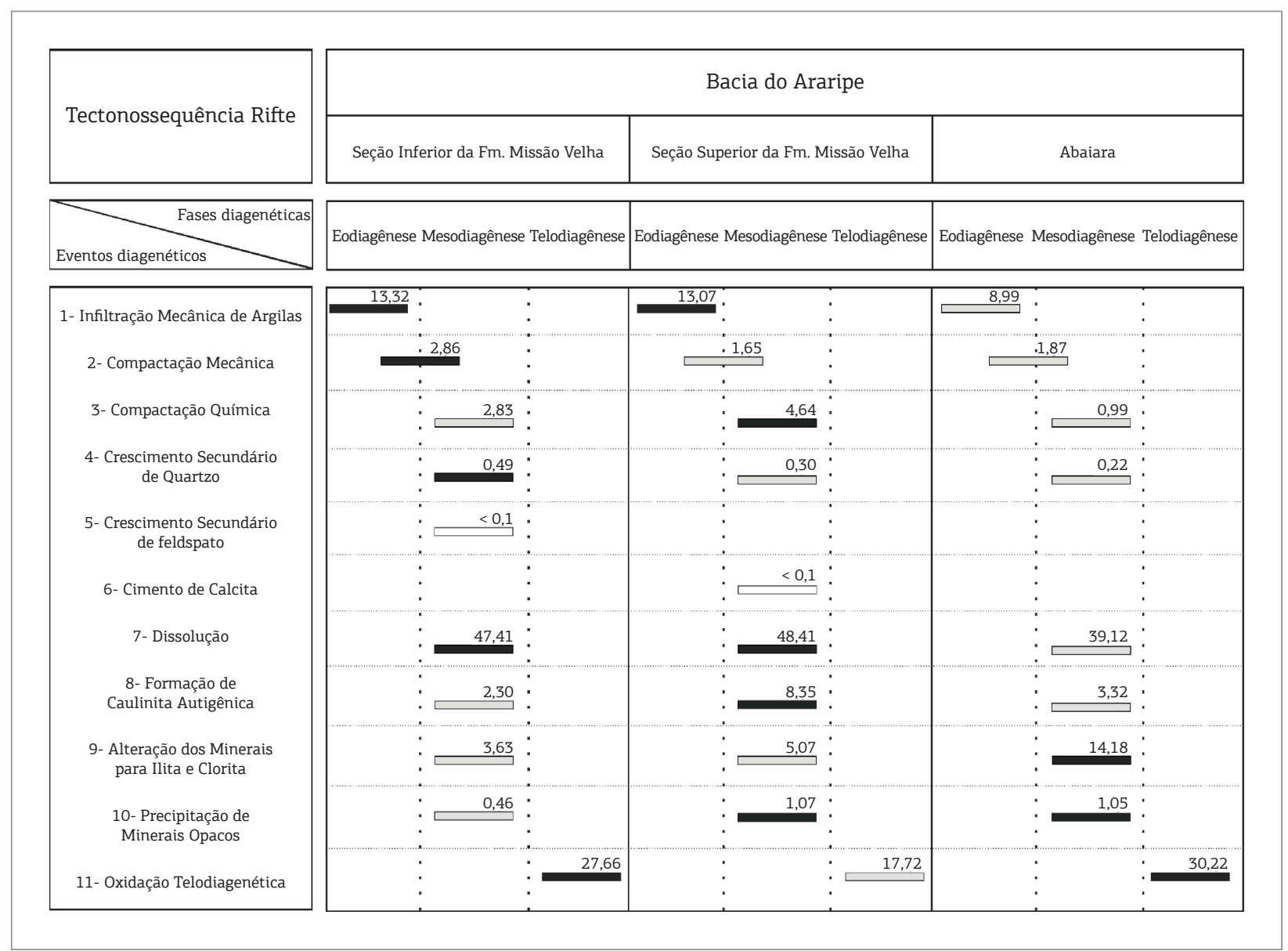

Figura 6. Quadro comparativo apresentando a história diagenética evolutiva e as respetivas percentagens de ocorrência de cada evento diagenético nas formações estudadas. 
em sua maioria, descontínuas e, localmente, nos arenitos da seção superior da Formação Missão Velha, contínuas, apresentando espessuras variadas. A textura em menisco ou ponte (Fig. 6A) é interpretada como tendo sido formada na zona vadosa pelos meniscos de água durante os períodos de seca. Segundo Bernard e Carrio-Schaffhauser (2003), as lamelas vão se localizar em zonas onde a pressão capilar preserva os fluidos, promovendo a reorganizaçáo do material argiloso. Assim, as primeiras partículas depositam-se desorganizadamente na zona onde o contato entre os grãos do arcabouço é mais próximo. Quando essa zona do poro está preenchida na totalidade pelos argilominerais desorganizados, novas películas vão ser depositadas progressivamente em conformidade com a interface água-ar, até que a sua orientação se torne tangencial à fronteira do menisco.

As rochas da seção superior da Formação Missão Velha, além de exibirem argilas infiltradas sob a forma de meniscos, apresentam ainda dois outros tipos de texturas de argilas infiltradas, não evidentes nas outras rochas, fato este que a distingue das demais unidades. Esses dois tipos são designados de texturas de encolhimento e de agregados/massas floculadas. O primeiro tipo resulta de um processo que consiste na perda de água presente no material argiloso, e o segundo tipo relaciona-se a condiçôes de estabilidade/estagnação que dão origem a massas argilosas que envolvem os grãos do arcabouço. As argilas infiltradas obliteraram localmente o espaço poroso da rocha e, consequentemente, inibiram parcialmente o desenvolvimento de fases diagenéticas posteriores.

\section{Compactação}

A compactação compreende duas fases, uma subsequente à outra, designadas nessa ordem de compactação mecânica e compactação química; essa última envolve um soterramento mais efetivo, sendo também denominada de dissolução por pressão. Nas rochas das formações em estudo, a compactação mecânica é reconhecida pelos três parâmetros que a caracterizam: rearranjo textural, fraturamento e esmagamento, com a geraçáo de pseudomatriz. O rearranjo textural é observado tanto em grãos mais rígidos, como o quartzo, como em grãos mais dúcteis, como as muscovitas e biotitas (Fig. 6B). No caso das muscovitas e biotitas, foi possível observá-las completamente dobradas, as quais, uma vez atingindo o ponto máximo de elasticidade, acabam por fraturar. Em minerais mais resistentes, por sua vez, como quartzo e determinados fragmentos de rocha, foi possível visualizar fraturamentos internos. Além disso, a pressão exercida pelos grãos mais rígidos sobre os mais dúcteis provoca o esmagamento desses últimos, que fluem pelos espaços intersticiais, originando a pseudomatriz. A pseudomatriz é geralmente constituída por argilominerais nas rochas das formaçôes Abaiara e seção superior da Formação Missão Velha, e por feldspatos alterados e fragmentos de rochas dúcteis na seção inferior da Formação Missão Velha.

A compactação química provoca a dissolução por pressão ao longo dos contatos grão a grão ou a dissolução a nível da rocha, sendo ocasionada pela sobrecarga sedimentar. Evidências da sua presença são os contatos interpenetrativos, principalmente os do tipo suturado (Fig. 6B), e as superfícies estilóliticas. Fatores como crescimentos secundários de quartzo e de feldspatos e de argilas infiltradas influenciam na intensidade de atuação da compactação, já que, ao passar por tais processos, a rocha fica com uma maior resistência. As rochas da seção inferior da Formação Missão Velha e Abaiara exibem contatos retos, côncavo-convexos, suturados e, particularmente, na Formação Abaiara, superfícies estilolíticas. Por fim, as rochas da seção superior da Formação Missão Velha são as que apresentam pouca evidência de compactação, sendo caracterizadas pela presença de grãos flutuantes, o que concede às rochas um empacotamento frouxo. A explicaçáo para o fato desses arenitos apresentarem evidências de maior compactaçáo química quando comparados com aqueles que lhe estão sobrepostos (Formação Abaiara), é que os mesmos contêm uma grande percentagem de argilas infiltradas. As argilas infiltradas ocorrem envelopando os grãos ou preenchendo os espaços intersticiais e impedem o contato grão a grão que irá promover a dissolução por pressão.

\section{Mesodiagênese}

\section{Crescimentos secundários de quartzo e feldspato}

Os crescimentos secundários de quartzo estão presentes nas rochas das formaçóes estudadas, sendo particularmente importantes naquelas em que o processo de infiltração mecânica de argilas está ausente ou pouco expressivo. A presença de argilas, quer seja sob a forma de cutículas ou de massas, cria uma barreira impermeável, impedindo o contato entre os fluidos instersticiais e a superfície do grão. Mesmo naquelas rochas onde o processo de infiltração mecânica de argilas esteve presente, ainda assim podem ser encontrados crescimentos secundários de quartzo. Nesses casos, as argilas encontram-se como cutículas descontínuas, o que pode justificar a ocorrência conjunta desses dois processos. Os crescimentos secundários de quartzo foram identificados pelas linhas de descontinuidade constituídas por impurezas (óxidos e hidróxidos de ferro e cutículas de argilas) que delimitam o grão original, e pelas faces retas com a mesma orientação ótica do mineral original.

Os crescimentos secundários de feldspato somente foram visualizados nas rochas da seção inferior da Formaçáo Missão Velha. O crescimento autigênico de feldspatos é reconhecido em lâmina delgada pelas faces retas dos grãos, 
e pelo fato da fase autigênica não apresentar as maclas presentes no grâo hospedeiro (Fig. $6 \mathrm{C}$ ).

\section{Cimentaçáo por calcita}

A calcita é precipitada quimicamente, preenchendo parcial ou totalmente os espaços porosos e/ou substituindo os grãos do arcabouço. Os fatores que controlam a sua precipitaçáo dependem da química da água, sobretudo, a razão $\mathrm{Mg} / \mathrm{Ca}, \mathrm{Eh}, \mathrm{pH}$, temperatura e $\mathrm{PCO}_{2}($ Klein \& Mizusaki 2007). Somente nas rochas da seção superior da Formação Missão Velha é que foi identificado esse tipo de cimento. O cimento de calcita manifesta-se pela precipitação de cristais bem desenvolvidos, de cristalinidade média, que ocupam parte do espaço intersticial e podem, em alguns casos, substituir grãos do arcabouço.

\section{Dissoluçáo}

Nas rochas estudadas, a porosidade primária foi reduzida durante a eodiagênese e início da mesodiagênese, em virtude da infiltração mecânica de argilas, como também pelos crescimentos secundários de quartzo e feldspatos. Ainda em ambiente mesodiagenético, porém mais tardio, ocorreu a dissolução dos cimentos e grãos do arcabouço originando a porosidade secundária. Esta resultou da lixiviação parcial ou total de alguns grãos de quartzo, feldspatos, de cimentos que compreendem os crescimentos secundários de felspato e de pseudomatriz.

\section{Formaçáo de caulinita autigênica}

A presença de caulinita autigênica foi observada em todas as rochas das formaçóes estudadas. Esse evento diagenético pode ocorrer em virtude de dois processos distintos: (1) precipitaçáo a partir da dissolução de silicatos instáveis durante a circulação de fluidos intersticiais, ou então, (2) substituição de grãos do arcabouço como muscovita, biotita e feldspatos e, portanto, constituir um mineral de substituiçấo. Em ambos os casos, seja como cimento ou como mineral de substituição, as caulinitas constituem uma fase autigênica de mesodiagênese. No primeiro caso, as caulinitas são identificadas nos espaços interpartícula por apresentar, em nicóis cruzados, birrefringência baixa, na ordem dos cinzentos, e em nicóis paralelos a típica textura em booklets (Fig. 6D). No segundo caso, quando as caulinitas constituem um mineral de substituição, essas ocorrem preferencialmente associadas às muscovitas (Fig. 6E), sendo também comum como substituição de biotitas, provocando um aumento no volume destes filossilicatos e a consequente diminuição da porosidade.

\section{Alteraçáo dos grãos para argilominerais}

A alteração dos grãos para illita e clorita ocorre graças ao aumento da instabilidade dos argilominerais com o aumento da profundidade. Para atingir o ponto de estabilidade, eles transformam-se em fases mais estáveis. Essa transformação, segundo Silva-Telles (1991), depende da concentração de determinados elementos químicos nos fluidos intersticiais.

Em lâmina delgada, esse processo foi reconhecido pela elevada birrefringência dos argilominerais quando ocorre a substituição da muscovita e da caulinita para illita. Em arenitos, a clorita normalmente ocorre como cimento, contudo, nas rochas em estudo tal processo náo foi identificado. Nas rochas estudadas, a clorita apresenta-se frequentemente como um mineral de substituição e tal processo está geneticamente vinculado à cloritizaçấo, principalmente da biotita.

\section{Precipitaçáo de minerais opacos}

O processo de precipitação de minerais opacos foi observado em todos os arenitos estudados, podendo ocorrer sob a forma de agregados ou como cristais alongados. Nas lâminas estudadas, predominam as piritas, sob a forma de cristais euédricos, as quais podem ter sido formadas em zonas de redução de sulfato por ação das bactérias anaeróbicas. Fatores como a presença de biotita e argilominerais (illita e esmectita), produto da substituição dos grãos, controlam fortemente a precipitação desse mineral, uma vez que ocorrem associados e ambos dependem da disponibilidade de ferro existente para sua precipitação (Fig. 6F).

\section{Telodiagênese}

\section{Oxidação}

A oxidação telodiagenética é originada em virtude das alteraçôes físico-químicas dos fluidos intersticiais. Nas rochas estudadas, esse processo encontra-se presente sob a forma de grandes massas em tons acastanhados e avermelhados que ocupam o espaço interpartícula. Em algumas lâminas, foi também possível visualizar os grãos recobertos por filmes (coatings) constituídos por óxidos e hidróxidos de ferro, ou então substituindo parcialmente os grãos do arcabouço (Fig. 6F).

\section{Integração da análise diagenética}

Com o intuito de comparar os resultados obtidos na análise diagenética dos arenitos da Tectonossequência Rifte, foi elaborado um quadro que apresenta a sequência temporal dos eventos de acordo com as fases diagenéticas, eodiagênese, mesodiagênese e telodiagênese e as suas percentagens de ocorrência.

A fase de eodiagênese é representada por dois eventos que atuaram em menor ou maior intensidade nos arenitos estudados, são eles: (1) infiltração mecânica de argilas e (2) início da compactação mecânica. A infiltração mecânica de argilas foi um evento de ocorrência ampla, que atingiu 
todos os arenitos estudados. Tal fato implica dizer que à época de deposição de tais rochas, provavelmente estaríamos numa eodiagênese continental sob clima árido. Nessas condiçōes, durante enxurradas episódicas e em profundidades rasas, as águas meteóricas infiltraram-se transportando consigo argilas detríticas em suspensáo que se decantaram sob a forma de cutículas (contínuas e/ou descontínuas), meniscos ou massas. Esse evento atuou com maior intensidade nos arenitos pertencentes à seçáo inferior e superior da Formação Missão Velha (Fig. 7). No decorrer dessa fase é iniciada a compactaçáo mecânica, a qual é evidenciada pela existência de pseudomatriz (esmagamento), rearranjo textural e fracturamento, que se prolonga até ao início da fase mesodiagenética.

A mesodiagênese é composta por nove eventos que se manifestaram nos arenitos estudados de forma distinta, sendo eles: (1) compactação mecânica; (2) compactação química; (3) crescimentos secundários de quartzo; (4) crescimentos secundários de feldspatos; (5) cimento de calcita; (6) dissolução; (7) formação de caulinita autigênica; e (8) precipitação de minerais opacos. Essa fase tem início quando o fluido intersticial se isola completamente em virtude do soterramento dos sedimentos até profundidades maiores e, dessa forma, os efeitos das águas superficiais sáo praticamente nulos. A compactação mecânica, que teve seu princípio ainda na eodiagênese, prossegue atuando de forma preponderante nos arenitos da seção inferior da Formação Missão Velha e nos arenitos da Formação Abaiara. Segue-se entâo a compactação química, com a dissoluçáo por pressão intergranular ou em nível da rocha reconhecida pela presença de contatos côncavo-convexos, suturados ou por superfícies estilolíticas. Esse evento foi mais marcante nos arenitos da seção superior da Formaçáo Missão Velha quando comparado às restantes formaçóes.

Os crescimentos secundários de quartzo e feldspato foram precipitados em torno dos gráos devido à dissolução e posterior circulaçáo de sílica e cátions nos fluidos intersticiais. Relativamente ao crescimento secundário de quartzo, podemos inferir que na seção inferior da Formação Missão Velha a circulaçáo dos fluídos teve um papel mais eficaz permitindo um maior predomínio desse tipo de cimento quando comparado às restantes formaçôes (Fig. 7). Por outro lado, $o$ crescimento secundário de feldspato e a cimentação de calcita denotam eventos de pouca importância nas formaçôes estudadas, tendo ocorrência local. Os crescimentos secundários promovem a redução da porosidade remanescente da compactação. A dissolução dos grãos e cimentos do arcabouço ocorre devido à circulação dos fluidos intersticiais e atuou com grande intensidade na seção inferior e superior da Formação Missão Velha. No caso da formação de caulinita autigênica, quer seja aquela decorrente da precipitação de silicatos instáveis ou aquela que atua como mineral de substituiçáo, estas apresentam valores mais elevados nas rochas da seçáo superior da Formação Missão Velha. Contudo, com relação à alteração dos minerais para illita e clorita, a maior percentagem desse evento foi verificada nos arenitos que integram a Formação Abaiara. Esses processos atuam no sentido de reduzir a porosidade secundária, anteriormente gerada. Por fim, na seçáo superior da Formação Missão Velha e na Formação Abaiara observa-se uma maior percentagem de ocorrência de precipitação de minerais opacos (Fig. 7).

A telodiagênese é representada por um único evento diagenético, expresso pela oxidação telodiagenética. Esse processo mostrou-se mais atuante nas rochas da Formação Abaiara, o que permite afirmar que as alteraçôes físico-químicas dos fluidos intersticais foram mais elevadas relativamente à seçáo inferior e superior da Formação Missão Velha (Fig. 7).

\section{CONCLUSÕES}

O estudo realizado nas formaçóes pertencentes à Tectonossequência Rifte que afloram na Regiáo CentroOeste do Vale do Cariri permitiu tecer as seguintes conclusóes:

- A seçáo inferior da Formação Missão Velha é composta por duas associaçóes de fácies que englobam depósitos externos aos canais fluviais e depósitos de canais fluviais arenosos, interpretadas como pertencentes a um sistema fluvial entrelaçado, levemente sinuoso. Texturalmente, tais rochas apresentam granulometria a variar de areia muito fina a muito grossa e congregam quartzo, feldspatos, fragmentos de rochas, muscovita, biotita, clorita e minerais pesados, sendo classificadas, segundo Folk (1968), como quartzarenitos e, locamente, como subarcóseo. A análise diagenética quantitativa permitiu inferir que, no estágio de eodiagênese, a infiltração mecânica de argilas e a compactação mecânica foram os eventos que desempenharam papel mais importante quando se compara essa seção com as demais unidades litoestratigráficas. No decorrer do estágio de mesodiagênese, os eventos que se destacaram foram os crescimentos secundários de quartzo e a dissolução dos constituintes que integram o arcabouço e o espaço intersticial. Por fim, o estágio de telodiagênese é caracterizado pela intensão oxidação devido à atuação das condiçóes meteóricas sobre os constituintes.

- A seção superior da Formação Missão Velha é representada por depósitos de canais fluviais arenosos a cascalhosos, pouco sinuosos, pertencentes a um sistema fluvial entrelaçado típico. As rochas que integram tal sistema apresentam granulometria a variar de areia muito fina a muito grossa constituídas por grãos de quartzo, feldspatos, fragmentos de rochas, muscovita, biotita, clorita, zircâo e turmalina e foram classificadas, segundo Folk (1968), 
como quartzarenitos. O estudo diagenético evidenciou que durante a deposição dessa seção, a infiltração mecânica de argilas manifestou-se de forma abundante. Durante o soterramento, os eventos diagenéticos mais importantes foram a compactação química, dissolução, formação de caulinita e precipitação de minerais opacos. Por fim, dentre as demais formaçóes estudadas, esta foi aquela na qual a oxidaçáo dos minerais foi menos atuante.

- A Formação Abaiara é caracterizada por três associações de fácies que congregam depósitos de frente deltaica/ prodelta proximal, planície deltaica e de canais fluviais sinuosos. As primeiras constituem um sistema deltaico, ao passo que os canais fluviais sinuosos compóem um sistema fluvial meandrante. Texturalmente, tais rochas apresentam arenitos muito finos a médios compostos por quartzo, feldspatos, fragmentos de rochas, filossilicatos e minerais pesados, sendo classificadas, segundo Folk (1968), em quartzarenitos. A análise diagenética concluiu que dentre as demais formaçôes, o estágio de eodiagênese nessa formação foi aquele que atuou com menos eficácia. O estágio de mesodiagênese é composto pelos eventos de alteração de minerais para clorita e illita e precipitação de minerais opacos. Por fim, o estágio de telodiagênese é representado pela intensa oxidação dos minerais.

\section{AGRADECIMENTOS}

Os autores agradecem ao Programa de Pós-Graduação em Geodinâmica e Geofísica da Universidade Federal do Rio Grande do Norte (UFRN), à Coordenação de Aperfeiçoamento de Pessoal de Nível Superior (CAPES) pelo financiamento da bolsa de estudos, ao Projeto Bacias Interiores UFRN/PETROBRAS, pela cessão dos dados, ao Laboratório de Geologia e Geofísica do Petróleo da UFRN e à Profa. Dra. Marcela Marques Vieira, pelas discussóes.

\section{REFERÊNCIAS}

Aquino M.M. 2009. A Formação Abaiara e o Arcabouço Tectonoestratigráfico da Região de Abaiara-Brejo Santo, Bacia do Araripe, NE do Brasil. Monografia de Graduação, Centro de Ciências Exatas e da Terra, Universidade Federal do Rio Grande do Norte, Natal, $84 \mathrm{p}$

Assine M.L. 1992. Análise Estratigráfica da Bacia do Araripe, Nordeste do Brasil. Revista Brasileira de Geociências, 22(3):289-300.

Assine M.L. 2007. Bacia do Araripe. Boletim de Geociências da Petrobras, 15(2):371-389.

Bernard X. \& Carrio-Schaffhauser E. 2003. Kaolinic meniscus bridges as an indicator of early diagenesis in Nabian sandstones, Sinai, Egypt. Sedimentology, 50:1221-1229.

Cardoso F.M.C. 2010. O grabén da Palestina: contribuição à estratigrafia e estrutura do estágio rifte na Bacia do Araripe, Nordeste do Brasil. MS Dissertation, Centro de Ciências Exatas e da Terra, Universidade Federal do Rio Grande do Norte, Natal, 107 p.

Castro D.L. \& Castelo Branco R.M.G. 1999. Caracterização da arquitetura interna das bacias do Vale do Cariri (NE do Brasil) com base em modelagem gravimétrica 3-D. Revista Brasileira de Geofísica, 17(2,3):129-144.

Choquette P.W. \& Pray L.C. 1970. Geological nomenclature and classification of porosity in sedimentary carbonates. American Association of Petroleum Geologists Bulletin, 54(2):207-250.

De Ros L.F. 2001. Petrologia Sedimentar. Notas de aula. Não publicado.

Folk R.L. 1968. Petrology of sedimentary rocks. Austin, Hemphill, 197 p.

Françolin J.B.L., Cobbold P.R., Szatmari P. 1994. Faulting in the Early Cretaceous Rio do Peixe Basin (NE Brazil) and its significance for the opening of the Atlantic. Journal Structural Geology, 16(5):647-661.

Klein C. \& Mizusaki A.M.P. 2007. Cimentação carbonática em reservatórios siliciclásticos, o papel da dolomite. Revista Pesquisas em Geociências, 34(1):91-100.
Matos R.M.D. 1992. The Northest Brasilian Rift System. Tectonics, 11(4):776-791.

Matos R.M.D. 1999. History of the northeast Brazilian rift system: kinematic implications for the breakup between Brazil and West Africa. Geological Society, 153:55-73.

Miall A.D. 1996. The geology of fluvial deposits: sedimentary facies basin analysis and petroleum geology. Berlim, Springer-Verlag, 586 p.

Morad S., Ketzer J.M., De Ros L.F. 2000. Spatial and temporal distribution of diagenetic alterations in siliciclastic rocks: implications for mass transfer in sedimentary basins. Sedimentology, 47(S1):95-120.

Ponte F.C. \& Ponte-Filho F.C. 1996. Estrutura geológica e evolução tectónica da Bacia do Araripe, Departamento Nacional de Produção Mineral, 4\%/10 ${ }^{\circ}$ Distritos Regionais, Relatório Interno, p. 68.

Schmidt V., McDonald D.A., Pratt R.L. 1977. Pore geometry and reservoir aspects of secondary porosity in sandstones. Americam Petroleum Geologists Bulletin, 25(2):271-290.

Scherer C.M.S., Jardim de Sá E.F., Córdoba V. C., Sousa D. C., Aquino M. M., Cardoso F. M. C. 2012. Evolução Estratigráfica da Seção Juro-Neocomiana da Bacia do Araripe, Nordeste do Brasil. In: SBG, Congresso Brasileiro de Geologia, 46, Anais, Santos. [CD- ROM]

Scherer C.M.S., Jardim de Sá E.F., Córdoba V.C., Sousa D.C., Aquino M.M., Cardoso F.M.C. 2014. Tectono-stratigraphic evolution of Upper Jurassic-Neocomian rift succession, Araripe Basin, Northeast Brazil. Journal of South American Earth Sciences, 49:106-122.

Silva-Telles Jr., A.C., Arai M., Coimbra J.C. 1991. Biocronostratigrafia e paleocologia da Bacia do Araripe. In: Ponte F.C., Dino R., Arai M., Silva-Telles Jr A.C. Geologia das Bacias Sedimentares Mesozóicas do Interior do Nordeste Brasil. Rio de Janeiro, Petrobrás, CENPES, SUPEP, DIVEX, SEBIPE. 